\title{
APPENDIX
}

\section{Differential Diagnosis of Vaginitis and Vaginosis}


Differential Diagnosis of Vaginitis and Vaginosis

\begin{tabular}{|c|c|c|c|c|}
\hline \multirow{2}{*}{$\begin{array}{l}\text { Diagnostic } \\
\text { Criteria }\end{array}$} & \multicolumn{4}{|c|}{ Condition } \\
\hline & Normal & $\begin{array}{l}\text { Bacterial } \\
\text { Vaginosis }\end{array}$ & $\begin{array}{l}\text { Candida } \\
\text { Vulvovaginitis }\end{array}$ & $\begin{array}{l}\text { Trichomonas } \\
\text { Vaginitis }\end{array}$ \\
\hline Vaginal pH & $3.8-4.2$ & $>4.5$ & $\leq .5$ (usually) & $>4.5$ \\
\hline Discharge & White, clear & $\begin{array}{l}\text { Thin, } \\
\text { homogeneous, } \\
\text { white, gray, } \\
\text { adherent, } \\
\text { often } \\
\text { increased }\end{array}$ & $\begin{array}{l}\text { White, curd- } \\
\text { like, clumpy; } \\
\text { sometimes } \\
\text { increased }\end{array}$ & $\begin{array}{l}\text { Yellow, } \\
\text { green, frothy, } \\
\text { adherent, } \\
\text { increased }\end{array}$ \\
\hline $\begin{array}{l}\text { Amine } \\
\text { odor (KOH } \\
\text { "whiff } \\
\text { test") }\end{array}$ & Absent & Present & Absent & $\begin{array}{l}\text { Present, but } \\
\text { not always }\end{array}$ \\
\hline Microscopic & Lactobacilli & $\begin{array}{l}\text { Clue cells, } \\
\text { coccoid } \\
\text { bacteria, } \\
\text { no WBCs }\end{array}$ & $\begin{array}{l}\text { Budding yeast, } \\
\text { pseudohyphae } \\
\text { with } \mathrm{KOH}\end{array}$ & $\begin{array}{l}\text { Trichomonads, } \\
\text { WBCs > } \\
10 \mathrm{HPF}\end{array}$ \\
\hline $\begin{array}{l}\text { Common } \\
\text { complaints }\end{array}$ & None & $\begin{array}{l}\text { Malodorous } \\
\text { discharge } \\
\text { (worse after } \\
\text { sex), potential } \\
\text { itching }\end{array}$ & $\begin{array}{l}\text { Itching, } \\
\text { burning, } \\
\text { stinging, thick } \\
\text { discharge; } \\
\text { dysuria } \\
\text { possible }\end{array}$ & $\begin{array}{l}\text { Frothy } \\
\text { malodorous } \\
\text { discharge, } \\
\text { vulvar } \\
\text { pruritus, } \\
\text { dysuria }\end{array}$ \\
\hline
\end{tabular}

$\mathrm{HPF}$, high-power field; $\mathrm{KOH}$, potassium hydroxide; $\mathrm{WBC}$, white blood cell. 